\title{
The performance of finisher-broilers under subsistence free- range system of production
}

\author{
V.N.Meremikwu ${ }^{1}$ and A.B.I.Udedibie ${ }^{2}$ \\ 'Department of Animal Science and Fisheries, Obubra Campus, Cross River University of Technology, \\ Cross River State . . Department of Animal Science, Federal University of Technology, Owerri Imo state.
}

\begin{abstract}
The growth and survival rate of finisher broilers (with minor feed supplementation) were determined under subsistence free-range poultry production in Nigeria. Three types of feed supplements (maize meal, full-fat soybean meal, and commercial grower ration) were used. $A 4^{\text {th }}$ group (the control) was fed intensively on commercial broiler finisher ration. After four weeks of brooding, the finisher broilers of equal weights were randomly selected and distributed to twelve households in each of the two selected locations (10 birds per household) for onward rearing on free-range for eight weeks. The control group was replicated four times (10 birds per replicate). Growth rate was significantly higher $(P<0.05)$ for the control intensive group and least for the free-range maize meal supplement group. The survival rate was $80-100 \%$, with the maize meal supplement group on the lowest range while the free-range commercial grower supplement was $100 \%$. Cost/kg live weight was least for the group on free-range commercial grower supplement and highest for the group on free-range maize meal supplement. This research has demonstrated the worth of providing finisher broiler chicks to farmers, rather than the day-old chicks traditionally purchased. This increases the survival rate of free-range chickens substantially and provides for vaccination programmes that may be too costly for farmers who only buy a small number of birds.
\end{abstract}

Keywords: Finisher broilers, subsistence, free-range, vaccination.

\section{Introduction}

Low per capita animal protein consumption in the developing countries has led to the search for alternative means of animal protein production. Coupled with the problem of low per capita protein consumption are the problems of increasing urbanization, rapidly expanding population, fragmentation of land holdings and poverty which have made it difficult for many people to take up livestock production on a reasonable scale. Unfortunately, the vast majority and bulk of livestock products (meat, milk, hides and fiber) are derived from animals that require substantial areas of land. These include cattle, sheep and goats, which are usually kept extensively, ranging over pastures and sometimes fallow fields after crops have harvested. Even though pigs can be penned and also have further advantage that they can be fed household waste, they require strong walls and fencing to restrain them. Also, religious and cultural taboos are generally considered major constraints to pig production in Nigerid. The poultry industry has in recent years occupied a leading role in meeting the animal protein need of people worldwide. Unlike other forms of meat animals that have either or both cultural/religious taboos attached to them, the chicken has neither religious nor cultural taboo in all parts of Nigeria. Poultry in general, has further advantage as an 
option for people who want to take up livestock enterprise but are constrained by land limitations. Unfortunately, conventional intensive farming system especially the use of broilers is beyond the scope of subsistence farmers. The problems of subsistence/scavenging poultry remain predation starvation, environmental stress and most importantly diseases. Newcastle disease is recognize as the most important cause of death and can cause mortalities approaching 100\% (Sonaiya et al.1992). Gumboro field viral infection is also described as a disastrous immunosuppresor leading to breakdown of immunity predominantly for Newcastle (Survashe, 1987). Apart from preventive vaccination, there is no effective treatment against these viral diseases by way of medication. While it is possible to achieve total control of the disease through a well-organized vaccination programme in commercial poultry keeping, it is almost impossible to achieve the same in free-range poultry due to the small and unplanned nature of the flock.

Bessei (1987) stated that, in the effort to improve egg and poultry meat supply, the development of both intensive and extensive production systems has to be considered. Whilst intensive poultry units are needed to satisfy the demands in the large cities, the improvement of scavenging poultry keeping (extensive) offers an opportunity to increase protein supply and to generate income for subsistence farmers". Low-cost improvements made in feeding, housing, disease control and introduction of improved breeds can lead to a considerable increase of production in extensive rearing system. This research was designed to supply subsistence farmers with broiler chicks which have been brooded and subjected to necessary vaccination programmes .The objectives were to determine the performance (mainly the growth and survival rate) of the birds on free-range system of production of subsistence urban farmers and the cost effectiveness of such a system in Nigeria.

\section{Materials and Methods}

The experiment involved comparison of four feeding regimes or treatments using finisherbroilers in a completely randomized design (CRD):

(a) -Intensive system on commercial broiler finisher ration as control.

(b) -Free-range system on maize meal supplement.

(c) -Free-range system on toasted full-fat soybean meal supplement.

(d) -Free-range system on commercial grower ration supplement.

Site of project.

The research was conducted in two different cities: Owerri in Imo State and Calabar in Cross River State in which an academic institution and households served as individual test sites. The test sites are: For Owerri (Federal University of Technology Owerri and households in Owerri urban. For Calabar (Ibrahim Babangida College of Agriculture Obubra and households in Calabar urban.

Procurement and brooding of the broiler chicks: Day-old Anak broiler chicks were obtained from commercial distributors. A total of 200 broiler chicks were used in each city. The brooding pens were heated some hours before the arrival of the chicks to avoid cold- shock. On arrival, the chicks were started on antibiotics and vitaminlmineral supplement from day one for seven days. They were also given the necessary vaccinations. The chicks were raised on deep-litter floor for four weeks. Feed and water were given ad- libitium. Feed offered and leftover were weighed and recorded for calculation of feed consumption rate and feed cost analysis for the production of the finisher broilers. 
Table 1: The crude protein, fat and crude fiber content of the test materials.

\begin{tabular}{|c|c|c|c|c|}
\hline \multirow{2}{*}{ Components $(\%)$} & \multicolumn{3}{|c|}{ Treatment Rations } & \multirow[b]{2}{*}{$D^{* *}$} \\
\hline & A (control) $)^{* *}$ & $\mathrm{~B}^{*}$ & $\mathrm{C}^{*}$ & \\
\hline Crude protein & .19 .00 & 33.00 & 8.80 & 14.50 \\
\hline Crude fat & 8.60 & 14.60 & 3.80 & 7.00 \\
\hline Crude fibre & 5.40 & 4.00 & 2.20 & 7.20 \\
\hline \multicolumn{5}{|c|}{$\begin{array}{l}\text { Adapted from: }{ }^{*} \text { Wallace and Chesson }(1995) \\
\quad{ }^{*} \text { Grand Cereals and Oil mills Ltd. Jos, Nigeria. (Vital Feeds). } \\
\text { A (control) }=\text { Commercial broiler finisher ration }\end{array}$} \\
\hline $\begin{array}{l}\mathrm{B}= \\
\mathrm{C}= \\
\mathrm{D}=\end{array}$ & $\begin{array}{l}\text { 1ll-fat soybean } \\
\text { al } \\
\text { ial grower ratic }\end{array}$ & & & \\
\hline
\end{tabular}

Distribution and management of experimental birds (finisher-broilers)

Interested households were selected and educated about the project. Selection was done based on the level of protection offered by the environment. Feeding troughs and drinkers were given to the selected households for constant water supply and minor feed supplementation. Some households were given energy source only (maize meal), others were given protein source only (toasted full-fat soybean meal). A third group was given commercial grower ration while the $4^{\text {th }}$ group was fed intensively on commercial broiler finisher ration. At the end of $4^{\text {th }}$ week of the brooding phase, the finisher broilers of equal weights were selected and distributed to the households ( 10 birds per household) for onward rearing on free-range for eight (8) weeks. A sample size of twelve (12) households was used per city and a random allocation of four (4) households per treatment. The control group was also replicated four times (10 birds per treatment). Each household was given a measuring cup that could contain $600 \mathrm{~g}$ of feed for daily feed supplementation. The remaining finisher broilers including runts and deformed birds were reared together and disposed without record. The control birds were fed only during the day since their counterparts on free-range had no access to feed at night.
Data collection and analysis

The birds were weighed weekly for determination of weight gains. Feed offered daily were weighed and recorded for the control group while a given quantity of feed ( $60 \mathrm{~g}$ per bird day) was given for the free-range group and the bulk of feed offered throughout the experimental period were summed up for feed cost analysis. Mortalities in all the treatments were recorded. Data obtained were subjected to analysis of variance (ANOVA) and when significant differences were detected, means were compared using Least Significant Difference (LSD) as described by Snedecor and Cochran (1967). The rearing phase lasted for eight (8) weeks i .e. a total of twelve (12) weeks from brooding.

\section{Results and Discussion}

Cost of production variables from day -one of the broiler chicks to four weeks (28days) are presented in table2. (Although the actual research started after week four (4) of the broiler chicks, it is however necessary to highlight some of the factors and inputs that will affect the cost and performance of the finisher broilers). Production costs for the two cities were averaged together because variations in the cost of production inpus were neither environmental nor inherent in the production system, rather they 
Table 2: Ratio of production variables to total production cost from day one to four weeks of age

\begin{tabular}{lcc}
\hline Variables & Cost in Naira (N) & Ratio (\%) \\
\hline Total production cost & $39,914.20$ & - \\
Feed & $9,72.80$ & 22.98 \\
Day-old broiler chicks & $18,000.00$ & 45.1 \\
(200) & $3,241.4$ & 8.1 \\
Brooding medication & $7,500.00$ & 18.8 \\
(including vaccination) & $2,000.00$ & 5.0 \\
Heating oil (kerosene) & 199.57 & - \\
Labour & Average production cost & \\
\hline
\end{tabular}

are technical. This is because the suppliers of poultry production inputs used to build their transportation costs into the cost of their goods. Thus cost of inpuis is always subject to where and how the supplies are made. For example, dayold broiler chick was 90.0 naira in Owerri at the time of the research while it was 92.0 naira in Calabar. Broiler starter ration was 900.0 naira in Owerri while it was 885.0 naira in Calabar.

From the analysis in Table 2, it is surprising to note that brooding medication, which is the single production variable that determines the survivability of broilers chicks to market weight, is among the least cost production variable. Farmers (both large and small scale), including some veterinarians in Nigeria do skip vaccination programmes (especially $\mathrm{i} / \mathrm{o}$ and IBD vaccination programmes), as well as some prophylactic treatments, in an effort to reduce cost especially in broiler farms and have therefore ran into additional cost for treatment as well as high degree of morbidity among the surviving birds. This explains why Ross Breeders (1999) in their exclusively training school on broiler management emphasized welfare for improving efficiency. This is in line with the findings of
Giambrone (1999), which showed that infectious bursal disease virus (IBD) induced immunosuppresion is an important cause of sub-optimal performance in chickens.

Table 3 shows the data on the performance of the experimental birds (the finisher broilers) from four weeks to twelve (12) weeks of age. The results of both sites were averaged together. It was not necessary to analyze location as a separate variable because the research was carried out in similar environments (urban centers), specifically in the capital cities of the two States. The same feed supplements (maize meal, full-fat soybean meal and commercial grower ration (vital feeds) were used. Even under varying environments (urban and rural), the direct method of assessing the scavengeable feed resource (SCFR) of free- range birds is cumbersome, time consuming and inaccurate (Sonaiya, 2004). Sonaiya et al $\left(2002_{b}\right)$ determined the SCFR based on live performance of the birds. The control intensive group had significantly $(p<0.05)$ higher average final body weight than the free-range groups due to the higher and standard balanced components of the ration. This is in line with the findings of Afzal et al 


\begin{tabular}{|c|c|c|c|c|c|}
\hline \multicolumn{6}{|c|}{$\begin{array}{l}\text { Table 3: The performance of the experimental birds (finisher broilers) from } \\
\text { week four to week twelve. } \\
\text { Treatment means }\end{array}$} \\
\hline Parameters & $A$ (control) & $B$ & $C$ & $D$ & $L S D$ \\
\hline Initial body weight (g) & 832 & 832 & 832 & 832 & \\
\hline $\begin{array}{l}\text { A verage final body wt. } \\
\text { (g) }\end{array}$ & $3.160^{\mathrm{a}}$ & $2.135^{\mathrm{b}}$ & $1.377^{\mathrm{c}}$ & $2.112^{b}$ & 0.41 \\
\hline $\begin{array}{l}\text { Average daily gain } \\
\text { (g\day) }\end{array}$ & $41.59^{\mathrm{a}}$ & $23.29^{\mathrm{b}}$ & $9.74^{\mathrm{c}}$ & $18.58^{6}$ & 5.696 \\
\hline $\begin{array}{l}\text { Average daily feed } \\
\text { intake }(\mathrm{g})\end{array}$ & $125.5^{\mathrm{a}}$ & $60.0^{6}$ & $60.0^{b}$ & $60.0^{b}$ & $\begin{array}{c}T \text {-cal=13, } \\
\text { T abular-t }=2.447\end{array}$ \\
\hline $\begin{array}{l}\text { F.C.R (g of feedig } \\
\text { of wt gain) }\end{array}$ & $3.017^{\mathrm{a}}$ & $2.842^{\mathrm{a}}$ & $6.465^{b}$ & $3.23^{\mathrm{a}}$ & 2.021 \\
\hline Mortality $(\%)$ & 3.33 & 3.33 & 20.00 & 0.00 & \\
\hline $\begin{array}{l}\text { Cost/kg live wt (in } \\
\text { naira) }\end{array}$ & 151.13 & 168.16 & 215.12 & 144.18 & \\
\hline Cost $/ \mathrm{kg}$ feed (in naira) & 42.60 & 75.00 & 37.10 & 30.00 & \\
\hline \multicolumn{6}{|c|}{$\begin{array}{l}\text { a, b, c, means within a row with different superscript are significantly different }(p<0.05) \\
\begin{array}{ll}\text { F, C, } \mathrm{R} \text { (feed conversion ratio) } \\
\text { A (control) } & =\text { Commercial broiler finisher ration } \\
\text { B } & =\text { free-range toasted full-fat soybean group } \\
\text { C } & \text { = free-range maize meal group } \\
\text { D } & \text { free-range commervial grower ration group }\end{array}\end{array}$} \\
\hline
\end{tabular}

(1999) that a balanced diet is essential for normal growth and optimum performance of chickens. The significant $(p<0.05)$ low final body weight of the free-range maize meal supplement group in comparison with the other free-range groups was due to the poor protein content of the meal (Table 1). This is consistent with the fact that the protein content of scavenging feed is far too low for optimum growth of village flock (Roberts $e t$ $a l$, 1994). The high performance of the free-range soybean meal supplement group could be attributed to the high fat and protein content of the meal (Table 1). This finding is supported by the reports of several workers, which showed the beneficial effects of fats in hot weather poultry feeding programmes. Mateos and Sell (1981) reported that higher fat content of a diet contributes to reduced heat production. Dale and Fuller (1979) also demonstrated that substitution of fat for carbohydrate in broilers (4-7 weeks old) increases the energy intake and reduces the specific dynamic effect of the diet, which helps the birds to cope better with stress. The comparable performance of the free-range (commercial grower ration supplement group) with the free-range (soybean meal supplement group) could be attributed to the effect of lowcost improvement in the nutrition of free-range poultry. Roberts et al (1994) reported that chicks grow faster if the household refuse is supplemented with a small amount of protein. The survival rate deduced from mortality rate (Table 3) was $80 \%-100 \%$. The $100 \%$ survival rate of the free- range (commercial grower ration supplement group) confirmed the findings of Roberts et al (1994) that if the nutrition of scavenging chicken is supplemented, they do not die and their chances of survival are further enhanced. This is also in line with the observations of Payne (1990) that free-range birds acquire part of their diet by scavenging for herbage, seeds and insects and that they usually remain very healthy. The high mortality rate of the free-range (maize meal supplement group) could be attributed to the low protein content of the meal (Table 1). This is supported by the 
findings of Afzal et al (1999), which showed that, deficiency of basic ingredients like amino acids, carbohydrates and fats results in decreased growth and has adverse effects on the immune responses of chicken (antibody titres are low) and the overall capacity of the animal to mount immune responses against diseases is low. Cost $/ \mathrm{kg}$ live weight was highest for the free-range (maize meal supplement group) and least for the free-range (commercial grower ration supplement). The high cost $/ \mathrm{kg}$ live weight of the group on maize meal supplement was due to the significantly $(\mathrm{p}<0.05)$ low final body weight at 12 weeks, while the relatively high cost $/ \mathrm{kg}$ live weight of the free-range (soybean meal supplement group) was due to the high cost of the feedstuff. The control intensive group had reasonable cost $/ \mathrm{kg}$ live weight due to the higher finished weight. Cost $/ \mathrm{kg}$ live weight was least for the free-range (commercial grower ration supplement group) with low but balanced nutrients. This was in agreement with the findings of Waldroup et al (1976) which showed that supplementation with limiting amino acids (methionine and lysine) gave better results in chicken in hot periods than high protein diets.

The results of this trial have shown that inputs to free-range poultry flock will be feasible if complemented by birds with high potential for production. The broiler, a breed that lends itself best to intensive system of production had performed well on free- range with minor feed supplement when brooded and distributed as finisher broilers. This system has improved the growth and survival rates of the free-range chicken. This finding is in line with the reports of Membratu (1995), that it is not appropriate to supply subsistence farmers with day-old chicks as protection against diseases cannot be assumed during the first months of life. Spradbrow and Samuel (1987) had earlier observed that free-range chicken have proved an elusive target for vaccination for several reasons. One of the reasons being that, the producers of commercial vaccines do not cater for the small flocks of Asian and African villages. They produce freeze-dried vaccines in vials that contain many (usually 1000) doses and these quantities are too large to be administered on subsistence rural flock. Membratu (1995) therefore advised that upgrading of indigenous birds should be achieved by the distribution of started and vaccinated pullets and cockerels.

\section{Conclusion}

This research has demonstrated the worth of providing vaccinated and brooded broiler chicks to farmers, rather than the day-old chicks traditionally purchased. This increases the survival rate of free-range chickens substantially and provide for vaccination programmes that may be too costly for farmèrs who buy only a small number of birds.

\section{References}

Afzal,H., Ahmad R., Ashfaque M and M.Arshad (1999). The immune response and cellular defence mechanism of chickens are weakened during food shortage. Feed restriction compromises the avian respiratory system leaving chickens vulnerable to respiratory infection. Feed $\operatorname{mix} 7: 26-28$.

Bessei W. (1987). Poultry International. Oct. 1987. Poultry Production in hot climates. A

WATT publication. P. 14.

Dale, N. M. and H.L. Fuller, (1979). Effects of diet composition on feed intake and growth of chicks under heat stress. Poultry Science, 58: 1529-1534. 
Giambrone J.J. (1999). Determining IBD immunity in broiler breeders. World Poultry, 15(9): 50.

Grand cereals and oil Mills Ltd (Subsidiary of UACN). KM 17. Zawan Round About, Jos Plateau State, Nigeria.

Mateos, G. G. and J. J. Sell (1981). Influence of fat and carbohydrate sources on rate of food passage of semi-purified diets of laying hens. Poultry Science, 60: 2, 112 $-119$.

Membratu Gebra- Yessus, (1995). Experience from an FAO Poultry Development Project in Ethiopia. In: Sustainable Rural Poultry Production in Africa by E. B. Sonaiya (ed). Pp57-59.

Payne, W. J.A. (1990). Introduction To Animal Husbandry in The Tropics. _Longman Singapore Publishers (PTE) Ltd. Pp684687.

Eberts, J. A., Gunaratne, S. P., Wickramaratne S. H. G and A.D. N. Chandrasiri, (1994). The survival and growth of village chicks given preferential access to household refuse with a creep feeder. Proceedings of the seventh AsianAustralian Association For Animal Production Congress, Bali, Indonesia. Pp34-35.

rreeders (1999). Ross Breeders goes back to school. World Poultry. 15 (99): 7.

Snedocor, G. W. and W. G. Cochran, (1967). Statistical Methods. Iowa State University Press Ames, Iowa $6^{\text {th }}$ ed.

Sonaiya, E. B., Olukosi, O. A., Obi, $O$ and K. M. Ajuwon, (2002). Vaccination and Scavengeable Feed Resource assessment for village poultry. In: Proceedings of the $3^{\text {:d }}$ Research Coordination Meeting of FAO/IAEA
Coordinated Research Project on Assessment of the Effectiveness of Vaccination Stategies against Newcastle Disease and Gumboro Disease using Immuno-assay Techniques for increasing Farmyard Poultry Production in Africa. Quatre Bornes, Mauritius, May 6-10,2002.

Sonaiya, E.B. (2004). Direct assessment of nutrient resources in free-range and scavenging systems. World's Poultry Science Journal 60:523-535.

Sonaiya, E. B., Laogun, E.A., Matamni, O,.Daniyan, O. C., Akande, E. E., Oguntade, R., Omoseibi, $O$ and V. E. Olori, (1992). Health and husbandry aspects of village extensive poultry productionin south Western Nigeria OP. Cit. pp34-41.

Spradbrow, P.B. and J.L. Samuel, (1987). Oral Newcastle disease vaccine in experimental chickens in Australia. In J. W. Copeland, ed., Newcastle disease in poultry. A new food pellet vaccine. ACIAR, Canberra, Monograph No. 5,pp. 44-49.

Survashe, B. D. (1987). Gumboro Disease a serious immunosuppressor. Poultry International, May 1987. A WATT publication. Pp.38-40.

Waldroup, P. W., MitehelI, R. J., Payne, J. R. and K. R. Hazen, (1976). Performance of chicks fed diets formulated to minimize excess levils of essential amino acids. Poultry Science 55: 243253.

Wallace, R. J. and A. Chesson, (1995). Biotechnology in Animal feeds and feeding. VCH Publishers inc. NY (USA). P.297.

(Recetved 22nd March, 2005: Accepted 5th Feb. 2007). 